Using Sound and Speech on the BBC Microcomputer 


\section{Macmillan Microcomputer Books}

General Editor: Ian Birnbaum (Adviser for Microelectronics in Education, Humberside LEA)

Advanced Graphics with the Acorn Electron

Ian O. Angell and Brian J. Jones

Advanced Graphics with the BBC Microcomputer

Ian O. Angell and Brian J. Jones

Assembly Language Programming for the Acorn Electron

Ian Birnbaum

Assembly Language Programming for the BBC Microcomputer,

second edition

Ian Birnbaum

Using Your Home Computer

Garth W.P.Davies

Beginning BASIC with the ZX Spectrum

Judith Miller

Using Sound and Speech on the BBC Microcomputer

M. A. Phillips

\section{Also from Macmillan}

Advanced Graphics with the Sinclair ZX Spectrum

Ian O. Angell and Brian J. Jones

Advanced Programming for the $16 \mathrm{~K} \mathrm{ZX81}$ Mike Costello

Beginning BASIC Peter Gosling

Continuing BASIC Peter Gosling

Practical BASIC Programming Peter Gosling

Program Your Microcomputer in BASIC Peter Gosling

Codes for Computers and Microprocessors P. Gosling and Q. Laarhoven Microprocessors and Microcomputers - their use and programming

Eric Huggins

The Sinclair ZX81 - Programming for Real Applications

Randle Hurley

More Real Applications for the ZX81 and ZX Spectrum Randle Hurley Programming in Z80 Assembly Language Roger Hutty

Digital Techniques Noel Morris

Microprocessor and Microcomputer Technology Noel Morris

The Alien, Numbereater, and Other Programs for Personal Computers -

with notes on how they were written John Race

Understanding Microprocessors B. S. Walker

Assembly Language Assembled - for the Sinclair ZX81 Anthony Woods 


\title{
Using Sound and Speech on the BBC Microcomputer
}

\author{
M. A. Phillips
}

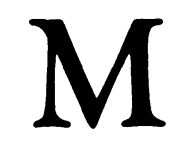

MACMILLAN 
(C) M.A. Phillips 1984

All rights reserved. No part of this publication may be reproduced or transmitted, in any form or by any means, without permission

Published 1984 by

Higher and Further Education Division

MACMILLAN PUBLISHERS LTD

Houndmills, Basingstoke, Hampshire RG212XS and London

Companies and representatives

throughout the world

\section{British Library Cataloguing in Publication Data}

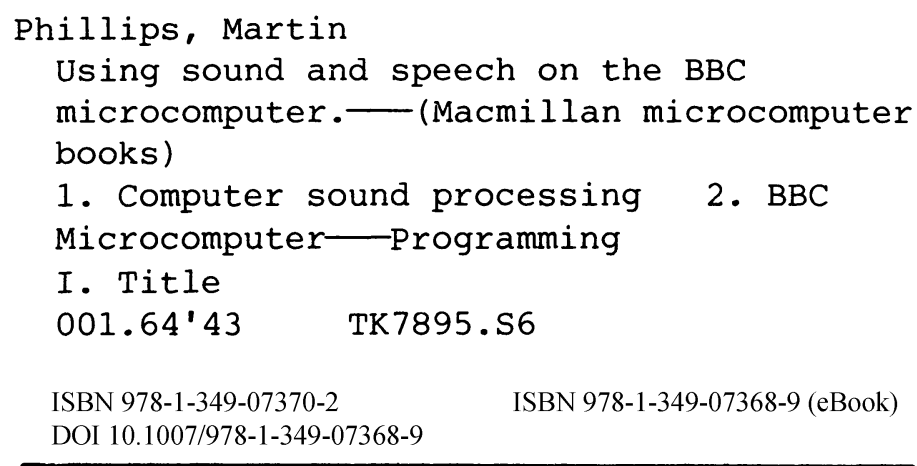




\section{Contents}

Preface vii

1. Introduction 1

Hints on Entering Programs 3

The Sound System Demonstrated 4

2. Understanding Sound 10

What is Sound? 10

The Three Elements of Sound 12 $\begin{array}{ll}\text { pitch, amplitude and timbre } & \\ \text { xing Waveforms } & 19\end{array}$

$\begin{array}{ll}\text { Mixing Waveforms } & 19 \\ \text { Summary } & 23\end{array}$

3. The Sound Statement 24

Commands and Statements 24

Control-G and *FX Calls 24

The Sound Statement $\quad 27$

The Noise Channel 32

The Channel Parameter $\quad 34$

$\begin{array}{ll}\text { The Sound Buffer } & 37\end{array}$

$\begin{array}{ll}\text { Summary } & 40\end{array}$

4. The Envelope Statement 41

An Overview 41

An Envelope Designer 45

Classifying Sounds 48

Envelope Parameters 48

step length

amplitude envelope

pitch envelope

notes on the parameter

Summary 
5. Music 58

Notation of Pitch 59

The Stave 63

Musical Notation $\quad 64$

Time Signatures $\quad 66$

Translating Music in Sound Parameters 67

Programming Musical Notation 68

Programming Instrument Sounds $\quad 76$

$\begin{array}{ll}\text { Summary } & 77\end{array}$

6. The Speech Synthesiser 78

Methods of Speech Synthesis 78

Theory of Speech Reproduction 79

Physical Hardware $\quad 82$

Using the Speech System 82

Using the Speech System from BASIC 83

Tones and Pauses 84

Compounding Words $\quad 85$

The Speech Buffer $\quad 85$

Speech Applications $\quad 86$

$\begin{array}{ll}\text { Summary } & 89\end{array}$

7. Assembly Language 90

The OSWORD Call 90

Using Event Handling 93

$\begin{array}{ll}\text { Appendix } 1 \text { - The Sound Buffers } & 98\end{array}$

$\begin{array}{ll}\text { Appendix 2 - The *FX Calls } & 106\end{array}$

Appendix 3 - Two Envelope Generators 108

Appendix 4 - Speech Synthesiser Vocabulary 116

$\begin{array}{ll}\text { Appendix } 5 \text { - The Pitch Parameter } & 120\end{array}$

$\begin{array}{ll}\text { Appendix } 6 \text { - Hardware } & 127\end{array}$

$\begin{array}{ll}\text { Index } & 131\end{array}$

Details of Cassette 133 


\section{Preface}

Most programs can be enhanced by the effective use of sound. If the programmer wishes to develop a variety of sounds then a range of skills is needed. First is a knowledge of the mechanism by which sounds are produced; second a knowledge of music; and third an ability to relate the computer sound and envelope parameters made by the computer. This book combines the basic elements of these three skills to give the reader sufficient background knowledge to make effective use of the BBC SOUND and ENVELOPE commands.

Throughout the book it is anticipated that readers will try out the various programs, experiment with them and program their own interesting sounds. It is not expected that the reader is an expert programmer and the programs have been written in such a way as to make typing them in as easy and error-free as possible.

I would like to thank Anne Kingston for her invaluable help with the chapter on music, Michael Free for the photography work and Acorn Computers for the permission to publish the circuit diagrams.

Martin Phillips 